\title{
RELASI MUSLIM DAN NASRANI TERKAIT PENDIRIAN GEREJA DI WILAYAH PERUMAHAN NON-DINAS TNI ANGKATAN LAUT DI DRIYOREJO GRESIK
}

\author{
Kasno \\ Universitas Islam Negeri Sunan Ampel Surabaya, Indonesia \\ E-mail: kasno.sudaryanto@yahoo.com
}

\begin{abstract}
This article examines the interfaith relation of Muslims and Christians in the process of establishment of churches in Perumaban Non-Dinas TNI Angkatan Laut in Driyorejo Gresik. The article concludes that the real interreligious relation in Driyorejo is very good. It is characterized by a relationship of mutual respect and tolerance in order to implement the teachings of their respective religions in the area. This relationship functionally indicates that the process of adaptation is very good. The harmony of inter-religious relation contributes to the creation of an orderly and safe society. Social-religious elements can be integrated together to create a solid and unified society. The harmony can be achieved because their religious and cultural values of society emphasize the accommodation and tolerant attitude. The social problems associated with the establishment of churches in the Perumaban indeed could lead to social unrest. Borrowing structural-functionalist theory, it can be stated that systemic balance is likely to change because of the influence of extra system. The public unrest indicates that the system is experiencing instability. However, the social system has an internal control mechanism that can stabilize the system after disorder. In the case of the establishment of churches, the community tend to choose legal approach as a means of controlling or resolving conflict.
\end{abstract}

Keywords: Muslims; Christians; the establishment of churches.

\section{Pendahuluan}

Konflik yang disebabkan persoalan rumah ibadah merupakan persoalan yang pelik dan sensitif. Problem ini dapat dilihat dari beberapa kerangka, antara lain: pertama, posisi negara. Sebagai 
komunitas bayangan yang merangkum aneka kepentingan masyarakat, negara didirikan atas kontrak semua kelompok dan elemen masyarakat. Hal ini merupakan gagasan etis modern tentang negara. Negara dengan sendirinya menjadi tempat kelompok-kelompok yang bisa melakukan transformasi menuju cita-cita yang diidealkan. ${ }^{1}$

Gagasan ini dapat diartikan bahwa negara menjadi tempat dan mekanisme transformasi yang disepakati, dengan sendirinya wilayah negara melahirkan entitas negara dan entitas warga. Warga adalah pemberi mandat dan negara adalah yang diberi mandat. Dalam konteks negara yang didirikan oleh banyak kelompok, maka negara harus menjamin kebebasan keyakinan dan keberagaman semua kelompok, bukan memberi hak luas kepada satu kelompok dan mendiskreditkan kelompok lain. Oleh karenanya negara harus memiliki seperangkat aturan hukum yang bisa menjadi patokan lalu lintas bernegara. Tentunya aturan hukum tersebut bukan untuk mengawasi dan mengintimidasi warga negara atau mendiskriminasikan kelompok agama lain.

Kerangka kedua adalah konflik sosial. Tidak dapat dipungkiri bahwa persoalan pendirian rumah ibadah seringkali berujung pada konflik sosial. Konflik terjadi ketika kontestasi untuk mencapai sebuah tujuan tidak memperoleh kanalisasi yang semestinya, sehingga melahirkan ketakpuasan. ${ }^{2}$ Konflik sosial senantiasa melibatkan dua kelompok sosial atau lebih, kelompok agama dalam hal ini juga merupakan kelompok sosial. ${ }^{3}$ Berbagai kelompok sosial dalam masyarakat di suatu wilayah memiliki posisi sendiri yang berbeda satu dengan lainnya. Karena kelompok sosial tertentu memiliki posisi, ia juga memiliki otoritas. Otoritas tersebut secara mendasar ditentukan oleh posisi basis sosial mereka dan kekuatan yang dimiliki dalam masyarakat untuk dapat melakukan hegemoni.

Adanya perbedaan agama yang disertai memuncaknya sensitivitas kecurigaan yang pada akhirnya akan menyebabkan terjadinya konflik sosial. Jika yang dimenangkan adalah kelompok mayoritas, maka yang terjadi adalah ketimpangan. Tentu saja agama minoritas yang memiliki

${ }^{1}$ Lihat gagasan tentang negara dalam Bennedict Anderson, Imagined Communities: Komunitas-komunitas Terbayang, terj. Omi Intan Naomi (Yogyakarta: Insist-Pustaka Pelajar, 2001), 35-37.

2 Alo Liliweri, Prasangka dan Konflike (Yogyakarta: LKiS, 2005), 254.

3 Lihat teori konflik Ralf Dahendrof dalam Goerge Ritzer dan Douglas J. Goodman, Teori Sosiologi Kontemporer, terj. Alimandan (Jakarta: Prenada Media, 2004), 143-153. 
kerentanan yang paling tinggi ketika hidup di komunitas masyarakat yang beragama mayoritas. ${ }^{4}$ Oleh karenanya kesadaran akan hak asasi manusia bagi komunitas beragama sangatlah urgen, mengingat bahwa seringkali absolutisme yang berbentuk dominasi dan hegemoni komunitas beragama mayoritas membuat komunitas minoritas merasa kesulitan bahkan ada keterbatasan untuk mengekspresikan dan menjalankan ritual keagamaannya.

Beberapa peristiwa konflik sosial yang disebabkan oleh persoalan rumah ibadat masih terus terulang dan belum ada model penyelesaian yang dapat diterima oleh semua pihak. Sederet peristiwa konflik karena persoalan rumah ibadat masih mewarnai kehidupan umat beragama di Indonesia. Dalam konteks penelitian ini, penulis ingin menelusuri problematika penolakan warga dan penutupan serta pemberhentian pembangunan rumah ibadat (gereja) di Driyorejo, Gresik. $^{5}$

Secara sosiologis, kondisi sosio-religius masyarakat Gresik sangat stabil dan bahkan Gresik dikenal sebagai kota 'Santri' ${ }^{6}$ yang berarti kondisi sosialnya sangat menjunjung tinggi nilai-nilai spiritual. Begitu kentalnya istilah tersebut, hampir-hampir seluruh gerak nafas kehidupan dalam masyarakat mengambarkan kesan sebagai masyarakat yang religius. Akan tetapi dalam proses pengembangan wilayah ekonomi dan sosial-budaya, pemerintah telah mengembangkan Gresik bagian selatan yang berdekatan dengan kota Surabaya, sebagai kawasan industri dan real-estate, yang sudah barang tentu sangat memerlukan kebutuhan infrastruktur seperti sekolah, tempattempat ibadat, sarana olahraga maupun sarana kesehatan. Salah satu kebutuhan infrastruktur tersebut adalah kebutuhan tempat ibadat, yaitu pendirian gereja di kawasan perumahan.

4 http: //www.lakpesdam.or.id/publikasi/348/pluralisme-dan-kerentanan-sosialdalam-hubungan-antaragama

${ }^{5}$ Konstelasi penganut agama turut memengaruhi konstelasi politik lokal yang masih didominasi politik aliran. Kabupaten Gresik merupakan daerah campuran budaya Arek dengan Madura. Kedua budaya sangat lekat dengan tipe budaya Islam tradisional yang sangat kuat memiliki patron-client. Pola aliran ini sangat terasa pada dua hal (1) konstelasi politik lokal, dan (2) jenis, tipe, model perluasan konflik yang muncul antara perusahaan dengan masyarakat atau perusahaan dengan pemerintahan lokal.

${ }^{6}$ Sebutan Kota Santri dikalangan masyarakat Jawa Timur karena nuansa religious sangat kental di kota ini dan dalam sejarahnya kota ini menjadi pusat penyiaran Islam di Pulau Jawa. Ada tiga wali dari Sembilan wali dimakamkan di kota ini antara lain Sunan Giri, Sunan Bonang, dan Sunan Drajat. 
Salah satu wilayah perumahan yang berupaya memenuhi kebutuhan infrastruktur tersebut adalah Perumnas Kota Baru Driyorejo, yang merupakan komplek perumahan yang diadakan oleh Komando Armada RI Kawasan Timur Pangkalan Utama TNI AL V yang merupakan perumahan non-dinas, jadi untuk masyarakat umum dan khususnya keluarga Besar TNI AL. Kebutuhan akan adanya rumah Ibadat di komplek Perumahan tersebut merupakan kebutuhan mutlak dan hak warga Negara yang harus dipenuhi. Dengan alasan untuk pembinaan masyarakat khususnya keluarga besar AL, maka Komandan Pangkalan Utama TNI AL V mengeluarkan surat izin pendirian empat Gereja antara lain: Gereja Kristen Jawi Wetan (GKJW), Gereja Kristen Bethany Indonesia (GBI), Gereja Pantekosta di Indonesia (GPdI) dan Gereja Katolik Santo Gabriel. ${ }^{7}$ Izin pendirian gereja-gereja tersebut ditindak lanjuti dengan pembangunan gedung dan fasilitas serta kegiatan peribadatan. Keberadaan gereja-gereja tersebut ternyata, kemudian menimbulkan protes dan penolakan oleh masyarakat sekitar dan timbul aksi-aksi demo sebagai wujud ketidaksetujuan mereka.

Menyadari bahwa persoalan pendirian rumah ibadah menjadi salah satu pemicu konflik, maka artikel ini akan menyoroti persoalan pendirian rumah ibadah dilihat dari perspektif sosiologis, lebih-lebih kaitannya dengan antarumat beragama yang semakin individualis. Di samping itu peneliti akan memotret dinamika konflik antarumat beragama yang disebabkan oleh persoalan pendirian rumah ibadah, sehingga dapat diketahui akar permasalahan yang sesungguhnya, apakah disebabkan persoalan regulasi dalam hal ini berlakunya Peraturan Bersama Menteri No. 9 dan 8 Tahun 2006 yang menjadi rujukan prosedur pendirian rumah ibadah dianggap masih memberatkan komunitas umat beragama minoritas, ataukah adakah faktor psikologis hubungan mayoritas dan minoritas yang berlainan keyakinan atau bahkan faktor lain yang belum terungkapkan.

Dalam konteks kajian kepustakaan, beberapa penelitian sudah dilakukan terkait problematika hubungan antarumat beragama, antara

\footnotetext{
7 Surat izin tertanggal 12 Nopember 2009 ditujukan kepada keempat Ketua Pembangunan Gereja tersebut dengan nomor surat: 163-20/03/14/lant V untuk Gereja Kristen Jawi Wetan, dan nomor: $165-20 / 03 / 14 /$ lant V untuk Gereja Kristen Bethany.
} 
lain: Hamzah Tualeka ZN, ${ }^{8}$ Zainuddin, ${ }^{9}$ Isnatin Ulfa, ${ }^{10}$ Muhammad Kholil, ${ }^{11}$ M. Khusna Amal, ${ }^{12}$ Syamsul Arifin, et. al, ${ }^{13}$ Titik Suwariyati, ${ }^{14}$ Ahmad Khalikin, ${ }^{15}$ M. Yusuf Asry, ${ }^{16}$ Akmal Salim Ruhan, ${ }^{17}$ Bashori A. Hakim, ${ }^{18}$ Mursyid Ali, ${ }^{19}$ Haidlor Ahmad, ${ }^{20}$ Ibnu Hasan Muchtar, ${ }^{21}$ dan lain-lain.

${ }^{8}$ Hamzah Tualeka ZN, "Konflik dan Integrasi Sosial Bernuansa Agama: Studi Tentang Pola Penyelesaian Konflik Ambon-Lease Dalam Perspektif Masyarakat" (Disertasi--IAIN Sunan Ampel Surabaya, 2008), 246-247.

9 Zainuddin, "Relasi Islam-Kristen: Konstruksi Elit Agama tentang Pluralisme dan Dialog Antarumat Beragama di Malang” (Disertasi--IAIN Sunan Ampel Surabaya, 2008).

${ }^{10}$ Isnatin Ulfa, "Perspektif al-Qur'an tentang Pluralisme Agama: Telaah Komparatif terhadap Pluralisme Agama dalam Tafsir al-Bayan dan Tafsir al-Mizan" (Tesis-Surabaya: PPs IAIN Sunan Ampel, 2003), iv.

${ }^{11}$ Muhammad Kholil, "Pluralisme Agama: Telaah Kritis atas Pemikiran Nurcholis Madjid” (Tesis-IAIN Sunan Ampel Surabaya, 2008), v.

${ }^{12}$ M. Khusna Amal, "Komitmen Agama Merajut Kerukunan Otentik di Perkotaan", Dialog Jurnal Penelitian dan Kegamaan, No. 65, Th. XXXI, Juli, 2008, 125-126.

13 Syamsul Arifin, et. al, Pluralisme Keagamaan di Pedasaan: Studi Pola Interaksi Sosial Tiga Kelompok Agama (Islam, Kristen, dan Budha) (Jakarta: Seri Penerbitan Ditjen BAGAIS Kemenag, 2004), 30.

14 Titik Suwariyati, "Studi Kasus Pembangunan Gereja Kristen Bethany Indonesia dan Gereja Katolik Santo Gabriel di Perumnas Kota Baru Driyorejo Kecamatan Driyorejo Kabupaten Gresik", Haidlor Ali Ahmad (ed.) Haidlor Ali Ahmad (ed.), Hubungan Umat Beragama: Studi Kasus Penutupan/Perselisiban Rumah Ibadat Jakarta: Badan Litbang dan Diklat Puslitbang Kehidupan Keagamaan Kementerian Agama RI, 2012), 128.

15 Ahsanul Kalikin, "Pendirian Rumah Ibadat dalam Perspektif PBM: Kasus Pencabutan IMB Gereja HKBP Pangkalan Jati Gandul Kecamatan Limo Kota Depok", Haidlor Ali Ahmad (ed.), Haidlor Ali Ahmad (ed.), Hubungan Umat Beragama: Studi Kasus Penutupan/Perselisiban Rumah Ibadat (Jakarta: Badan Litbang dan Diklat Puslitbang Kehidupan Keagamaan Kementerian Agama RI, 2012), 190-210.

${ }^{16}$ M. Yusuf Asry, "Studi Kasus tentang Perselisihan, Pendirian Rukmah Ibadat di Kota Tangerang Selatan Provinsi Banten", Haidlor Ali Ahmad (ed.), Haidlor Ali Ahmad (ed.), Hubungan Umat Beragama: Studi Kasus Penutupan/Perselisihan Rumah Ibadat (Jakarta: Kementerian Agama RI, Badan Litbang dan Diklat Puslitbang Kehidupan Keagamaan, 2012), 1-56.

${ }^{17}$ Akmal Salim Ruhana, "Studi Kasus Perselisihan terkait Pendirian, Penertiban, dan Penutupan Rumah Ibadat di Kota dan Kabupaten Bogor Jawa Barat", Haidlor Ali Ahmad (ed.), Haidlor Ali Ahmad (ed.), Hubungan Umat Beragama: Studi Kasus Penutupan/Perselisiban Rumah Ibadat (Jakarta: Kementerian Agama RI, Badan Litbang dan Diklat Puslitbang Kehidupan Keagamaan, 2012), 58-118.

${ }^{18}$ Bashori A. Hakim, "Studi Kasus Perselisihan tentang Pendirian, Penertiban, dan Pentupan Rumah Ibadat di Kabupaten Badung-Bali”, Haidlor Ali Ahmad (ed.), Haidlor Ali Ahmad (ed.), Hubungan Umat Beragama: Studi Kasus Penutupan/Perselisiban 
Artikel ini memiliki kekhasan dari sudut pandang maupun fokusnya. Terdapat sikap apriori yang berkembang dalam masyarakat terkait dengan misi Kristen mengembangkan ajarannya, karena wilayah Gresik dianggap sebagai Kota Santri. Maka, pendirian gerejagereja di wilayah Gresik dianggap menodai eksistensi kota Gresik yang Islamis, dan faktor pelanggaran terhadap PBM Kementerian Agama dan Kementerian Dalam Negeri RI Nomor 8 dan Nomor 9 Tahun 2006. Fokus penelitian tentang Pendirian rumah ibadat dan konflik yang melibatkan berbagai faktor terutama sentimen religiositas subjektif yang bersifat simbolis inilah yang belum dilakukan dalam penelitian atau artikel terdahulu.

\section{Relasi Antarumat Beragama di Driyorejo Gresik}

Gresik dikenal sebagai kota santri, kota wali, atau kota berhias iman. Secara sosiologis, masyarakat Gresik sangat akomodatif dan memiliki toleransi yang cukup tinggi terhadap varian komunitas yang memiliki identitas budaya, suku, maupun agama yang berbeda. Meskipun demikian, masyarakat Gresik bukan berarti bersikap permisif terhadap masalah-masalah yang sangat prinsipil seperti persoalan norma dan agama.

Masyarakat Gresik dianggap masih menerima perbedaan, namun ketika terdapat aktivitas yang dianggap menyinggung perasaan masyarakat dan lingkungan sekitarnya, seperti melanggar peraturan yang ditetapkan, maka akan ada reaksi. Meski demikian masyarakat Gresik masih memiliki toleransi baik untuk menyelesaikan tiap konflik

Rumah Ibadat (Jakarta: Kementerian Agama RI, Badan Litbang dan Diklat Puslitbang Kehidupan Keagamaan, 2012), 175-209.

19 Mursyid Ali, "Studi Kasus Rumah Ibadat di Kota Palangkaraya Kalimantan Tengah", Haidlor Ali Ahmad (ed.), Haidlor Ali Ahmad (ed.), Hubungan Umat Beragama: Studi Kasus Penutupan/Perselisiban Rumah Ibadat (Jakarta: Kementerian Agama RI, Badan Litbang dan Diklat Puslitbang Kehidupan Keagamaan, 2012), 212-243.

20 Haidlor Ahmad, "Studi Kasus Perselisihan terkait Pendirian, Penertiban dan Penutupan Rumah Ibadat di Kota Kupang Nusa Tenggara Timur", Haidlor Ali Ahmad (ed.), Haidlor Ali Ahmad (ed.), Hubungan Umat Beragama: Studi Kasus Penutupan/Perselisiban Rumah Ibadat (Jakarta: Kementerian Agama RI, Badan Litbang dan Diklat Puslitbang Kehidupan Keagamaan, 2012), 246-302.

21 Ibnu Hasan Muchtar, "Studi Kasus terkait Perselisihan, Penertiban, dan Penutupan Rumah Ibadat di Kota Penelitian di Kota Jayapura", Haidlor Ali Ahmad (ed.), Haidlor Ali Ahmad (ed.), Hubungan Umat Beragama: Studi Kasus Penutupan/Perselisiban Rumah Ibadat (Jakarta: Kementerian Agama RI, Badan Litbang dan Diklat Puslitbang Kehidupan Keagamaan, 2012). 
dengan mekanisme musyawarah. Ini membuktikan bahwa masyarakat Gresik sangat arif menjaga nilai-nilai toleransi terhadap keberadaan agama atau kepercayaan yang berbeda dalam masyarakat. H. Makmun, salah seorang tokoh dari Ormas keagamaan, menyatakan bahwa "apapun permasalahannya, jika dimusyawarahkan dengan baik pasti terselesaikan. Masalah agama jangan membawa pejabat, mari kita musyawarah dengan baik agar masalah terselesaikan". ${ }^{22}$ Pandangan tokoh masyarakat ini dapat dijadikan rujukan untuk membaca situasi sosial dan keagamaan masyarakat Gresik.

Soal relasi antarumat beragama, masyarakat Driyorejo-dalam lokasi penelitian—sangat arif menjunjung toleransi antarmereka. Hal ini tampak dari hubungan antara tokoh lintas agama terutama yang terwadahi dalam Forum Kerukunan Umat Beragama (FKUB). Berbagai kegiatan yang mendukung serta memperkuat kerukunan antarumat beragama telah dicanangkan sebagai program kerjanya. Kegiatan silaturahmi antartokoh atau majelis agama telah menjadi agenda utama bagi FKUB. Sebagaimana dijelaskan oleh sekretaris FKUB:

“...Pengurus FKUB memprogramkan kegiatan anjang sana dari agama satu ke agama yang lain, acaranya saling tukar informasi dan pengalaman dari tuan rumah kegiatan dari masing-masing agama yang diakhiri dengan acara makan bersama. Makanan disediakan oleh tuan rumah dan dengan acara ini masing-masing bisa mengenal dari dekat dan hubungan menjadi semakin akrab. Di antara yang hadir tidak canggung dan merasa asing. ${ }^{23}$

Keadaan yang digambarkan Toha juga diamini pengurus lainnya. Sebagaimana diceritakan oleh $\mathrm{H}$. Yarham, tokoh agama yang tergabung dalam FKUB Gresik ini, juga mengiyakan ketika ditanya tentang kegiatan silaturrahmi dalam bentuk anjangsana antartokoh. Ia memberikan contoh ketika Edy Prasetyaningsih, Pendeta Kristen Jawi Wetan (GKJW) yang lama bertugas di Gresik pindah ke GKJW Mojokerto. Ia mengisahkan:

“...Pada tanggal 18 Oktober 2014 bertempat di aula samping Gereja GKJW Jln. Panglima Sudirman Gresik, teman-teman Pengurus FKUB Gresik dari semua perwakilan agama hadir pada acara perpisahan Edy Prasetyaningsih (Pendeta GKJW Gresik) yang pindah tugas ke GKJW Mojokerto. Kegiatan pamitan berjalan

${ }^{22}$ H. Makmun (tokoh Agama NU Gresik), Wawancara, Gresik 16 Mei 2014.

23 Muhammad Toha (Kepala Balai Diklat Surabaya), Wawancara, Gresik 18 April 2014. 
begitu akrab dan secara psikologis demikian menyatu. Tidak ada jarak di antara undangan yang berbeda agama tersebut. Bahkan hadir juga para pendeta Kristen dari Surabaya dan Sidoarjo mereka akrab saling mengenalkan diri”.

Selanjutnya pak Haji Yarham juga menceritakan bahwa:

"Kawan-kawan umat Buddha dan juga Hindu juga tidak ragu mengundang kawan-kawan yang beragama lain, apabila punya hajat, bahkan salah seorang pengurus FKUB dari unsur agama Hindu yang menjadi anggota DPRD Kabupaten Gresik, Wongsonegoro, SE, SH, M.Si, tidak ingin melepaskan diri dari keanggotaan FKUB karena terkesan dengan kebersamaan tersebut. Bentuk rasa syukur atas keakraban tersebut semua pengurus FKUB dibelikan jaket... keakraban dan kebersamaan tersebut Nampak menyatu ketika mengadakan studi banding ke Bali, Nampak keguyuban dan kebersamaan di antara para tokoh agama tersebut...”.

Hal senada juga diungkapkan oleh M. In'am, tokoh Muhammadiyah Gresik yang juga pengurus FKUB Gresik, bahwa hubungan antar-umat di Gresik baik-baik saja, tetapi apabila mereka tidak mentaati aturan kita mesti harus tegas. In'am mengatakan:

"Yang saya ketahui dan rasakan di lingkungan rumah tinggal maupun organisasi, hubungan antara umat beragama cukup harmonis. Kata kuncinya adalah saling mengerti dan menghormati sebagai implementasi dari Peraturan Bersama Menteri Agama dan Menteri Dalam Negeri Tahun 2006 sebagai pedoman hidup hubungan antarumat beragama". ${ }^{24}$

Pernyataan In'am tersebut juga diamini tokoh agama Katolik, Yohanes Irfan, yang menyatakan bahwa kerukunan dan harmoni dalam masyarakat berbeda agama itu juga nampak dalam kegiatan sosial. Irfan menegaskan bahwa dalam kehidupan sehari-hari beliau sudah menyatu dalam masyarakat yang berbeda latar keagamaan. ${ }^{25}$

Hubungan kondusif dan toleran juga dapat dilihat pada aktivitas yang saling menghormati dan membantu di bidang ketertiban dan keamanan, seperti dilakukan oleh Gerakan Pemuda (GP) Ansor Gresik periode 2012-2016. Mereka melakukan sosial budaya salah satunya adalah "bersilaturahmi dengan pengurus Tempat Ibadat Tri Darma (TITD) Kim Hin Kiong atau Klenteng Kim Hin Kiong di Jalan Dr. Setiabudi Gresik. ${ }^{26}$

${ }^{24}$ M. In'am (tokoh Muhammadiyah Gresik yang juga pengurus FKUB Gresik), Wawancara, Gresik 9 November 2014.

${ }^{25}$ Yohanes Irfan (tokoh agama Katolik), Wawancara, Gresik 4 November 2014.

${ }^{26}$ Ashadi Iksan (pengurus GP Ansor Gresik), Wawancara, Gresik 4 November 2014. 
Fakta kerukunan ini tidak hanya dalam tataran silahturahmi antartokoh atau pimpinan agama, tetapi semangat kerukunan ini ditunjukkan dengan berbagai kegiatan kerjasama yang nyata, baik di bidang sosial keagamaan, ekonomi maupun budaya. Dalam kegiatan sosial keagamaan, misalnya, peran Banser yang menjadi bagian dari GP Ansor selama ini selalu membantu mengamankan berbagai harihari besar seperti Natal dan lain sebagainya. Sebaliknya apabila GP Ansor melakukan kegiatan, misalnya pelantikan pengurus, pihak kelenteng TITD akan membantu mengamankan atau menunjang kebutuhan lain yang bersifat sosial dan budaya. Kegiatan silaturahmi GP Ansor ke TITD Kim Hin Kiong adalah bagian yang merupakan salah satu dari program yang sinergi untuk kerukunan umat beragama yang memberi manfaat kepada masyarakat. ${ }^{27}$

Pun hubungan Muslim dengan komunitas agama lain, di mana umat Islam dan Hindu di Desa Pengalangan Kecamatan Menganti Kabupaten Gresik sangat harmonis, sehingga dapat dikatakan bahwa desa ini adalah miniatur kerukunan antarpemeluk agama. Terdapat dua pemeluk agama yang berbeda dan dapat hidup saling berdampingan di daerah ini, dan mereka mempunyai relasi yang cukup harmonis. ${ }^{28}$

Tidak hanya kerukunan antar-mereka semata, pemberian bantuan keuangan juga diusahakan oleh Gereja yang menyantuni Rp.150.000 perbulan untuk 250 orang miskin. Pula, Yayasan Kasih Bangsa sering diadakan pengobatan gratis, ${ }^{29}$ dan masih banyak lagi kegiatan-kegiatan sejenis yang dilakukan oleh majelis-majelis agama di Gresik sebagai wujud positifnya hubungan antar-agama.

Dari data tersebut dapat dikatakan relasi antarumat beragama di Gesik relatif rukun dan harmonis. Masyarakat Gresik tampaknya telah membangun hubungan sosial dengan baik. Dalam kerangka teori fungsionalisme struktural Parsonian, kondisi relasi antarumat beragama di Gresik memiliki mekanisme stabilitas fungsional, di mana masing-masing elemen atau unsur yang mendukung dalam satu kesatuan sistemik dan dapat menjalankan semua fungsinya secara baik. Asumsi dasar dari pendekatan struktural fungsionalisme bahwa

27 Ibid.

${ }^{28}$ Sumber: http://coratcoretanakbangsa.blogspot.com/2012/02/alangkah-indahnya - kerukunan-antar-umat.html

${ }^{29}$ Yohanes Irfan, Wawancara, Gresik 14 November 2014. 
suatu sistem sosial cenderung mempertahankan keseimbangan sistemik (equilibrium) antarelemen pendukungnya.

Berdasar pada analisis fungsionalisme struktural, bahwa fungsi dari lembaga-lembaga keagamaan pada masyarakat Gresik dapat mempertahankan keseimbangan sistemnya, yakni goal attainment. Ini dapat dilihat dari aksi masing-masing penganut keagamaan. Para tokohnya dapat menjalankan fungsi sinergis keagamaannya, yakni membangun silaturahmi secara intensif. Selain itu kerjasama lintas agama juga turut memperkokoh tindakan praktis dalam ruang sosial. Elemen-elemen sosial keagamaan yang ada dalam struktur masyarakat Gresik pun dapat beradaptasi dengan baik.

Tindakan adaptasi antar-elemen sosial keagamaan itu bermuara pada sikap akomodatif dan toleransi masyarakat. Sikap ini sebenarnya bersumber dari usaha mengaktualisasi nilai-nilai keagamaan yang dianut oleh masing-masing penganut keagamaan. Meminjam istilah Fungsionalisme Struktural Parsonian, sikap ini dikatakan sebagai sistem tindakan kepribadian (personal system). Sistem kepribadian menunjukkan bahwa aktor-aktor sosial (baca: umat beragama) memiliki kemampuan untuk mendefinisikan tujuan dan memobilisasi sumber-sumber untuk merealisir kerukunannya. Sistem tindakan kepribadian dapat memberi arah dan memobilasi kepribadian umat beragama agar menciptakan harmoni beragama sebagai goal attainment.

Ajaran Islam, misalnya, menunjukkan dasar-dasar toleransi dalam Islam sebagaimana yang tertuang salah satunya Q.S. al-Baqarah [2]: 256 dan Q.S. al-Kâfirûn [109]: 6, di mana keberadaan dan penghormatan atas hak-hak beragama sangat dijaga, diterima, dan diakui eksistensinya apapun agamanya.

Seluruh pesan dasar ajaran Islam turut mempengaruhi sikap kohesif masyarakat Gresik terhadap eksistensi agama lain. Dengan pola adaptasi antar-elemen lembaga keagamaan ini, situasi harmoni antarmasyarakat dapat tercapai. Selain itu, fungsi-fungsi sosial keagamaan ini ditunjang oleh nilai-nilai religiositas masyarakat Gresik. Menurut Parsons, sistem kebudayaan (cultural system) merupakan nilainilai yang dapat mengarahkan atau memotivasi aktor atau penganut agama dalam bertindak. Nilai-nilai religiositas masyarakat Gresik diwujudkan dengan berbagai peristiwa sosial kemasyarakatan yang disebut sebagai fungsi latency. Pada dasarnya fungsi ini bertujuan memelihara pola dan dinamika antarsub-sistem, selain juga bertindak sebagai pemelihara dan memperbaiki motivasi bagi pola-pola individu 
sosial-kultural. Dalam konteks relasi antarumat, fungsi ini merupakan saluran untuk mencapai konsensus dengan menggunakan nilai-nilai sosial-kultural sebagai common ground dalam membingkai kerukunan antarumat. Inilah yang dianggap sebagai proses latensi sebagai prasyarat terjadinya fungsi-fungsi berhubungan. Dalam bentuk sosialnya, fungsi latensi dapat diwujudkan antara lain dalam bentuk kegiatan saling mengunjungi dan kerjasama kemasyarakatan, seperti upacara pelepasan salah seorang Pendeta Jawi Wetan Ibu Edy yang pindah tugas dari Gresik ke Mojokerto atau seperti kegiatan pengobatan gratis massal yang dilakukan umat Katolik Gresik untuk masyarakat sekitar yang berasal dari berbagai antarpemeluk agama yang berbeda.

Namun, sebagaimana diungkapkan oleh Talcott Parsons, sistem tersebut cenderung menuju ke arah pemeliharaan keseimbangan diri yang meliputi pemeliharaan batas dan hubungan antara bagian-bagian, mengendalikan lingkungan yang berbeda dan mengafirmasi kecenderungan untuk merubah sistem dari dalam. Dengan asumsi teoretik ini, sistem sosial sebenarnya cenderung rentan oleh perubahan.

Dalam sistem kemasyarakatan di Gresik, perubahan interaksi sosial antarumat beragama juga sering terjadi. Beberapa kasus yang berkembang di Gresik seperti aktivitas non-Muslim yang mendapat reaksi masyarakat misalnya kegiatan rumah Ibadah Kristen di Benjeng, Pendirian Pura di Mondoluku, Gereja Pantekosta di Indonesia (GPdI) di Perumahan Gresik Kota Baru Driyorejo, Gereja Kristen HKBP (Huria Kristen Batak Protestan) di Randegansari, dan yang terakhir-yang juga menjadi fokus artikel—adalah didirikannya gereja-gereja yang diprakarsai oleh Pangkalan Utama Angkatan Laut (Lantamal V). ${ }^{30}$

Pembangunan gereja yang diinisiasi oleh Pangkalan Angkatan Laut $\mathrm{V}$ di lingkungan sekitar perumahan Non-Dinas Angkatan Laut Kota Baru Driyorejo Gresik memperoleh dukungan dari instansi pemerintah, yaitu Lantamal V. Pembangunan gereja ini diawali dengan proses surat-menyurat baik dari angkatan laut kepada Bupati Gresik, pihak panitia pembangunan gereja, pihak gereja Kristen Bethany, maupun pihak Gereja Katholik. Pembangunan gereja-gereja ini mendapat penolakan yang masif dan berujung pada penghentian dan

30 Pemerintah Kabupaten Gresik, Badan Kesatuan Bangsa dan Perlindungan Masyarakat Kabupaten Gresik, 2014. 
pengalihfungsian bangunan gedung gereja menjadi fasilitas umum selain tempat ibadah. ${ }^{31}$

Sampai saat ini belum ada aktivitas lanjutan pasca-penghentian aktivitas pembangunan, peribadatan dan penurunan simbol-simbol keagamaan di lokasi tersebut. Yang ada adalah bangunan setengah jadi yang belum dimanfaatkan. Rumput di halaman meninggi di kiri-kanan bangunan. Masyarakat menunggu aksi berikutnya, baik dari pihak Muslim, Kristiani, maupun Katolik. Kondisi saling menunggu atau saling jaga jarak di antara kedua belah pihak nampaknya di balik itu mereka berharap ada mediasi yang tulus untuk penyelesaian masalah tersebut.

Kasus pendirian rumah ibadat ini sempat mengusik keharmonisan hubungan antarumat beragama di Kabupaten Gresik sebagaimana diungkapkan oleh Yohanes Irfan, pengurus gereja dan pengurus FKUB Kabupaten Gresik bahwa "selama ini hubungan antarumat beragama di Gresik tidak ada masalah dan toleransi antarumat beragama terjalin baik. Terkait pendirian tempat ibadah ini memang ada masalah. Penutupan rumah ibadat di Driyorejo itu mengakibatkan kekecewaan bagi umat Katolik di sana. Penolakan keberadaan gereja tersebut merupakan bentuk ketidak-toleransian umat Islam Gresik. Mengapa penolakan itu tidak semenjak awal, tetapi justru terjadi saat gereja sudah hampir selesai pembangunannya". ${ }^{2}$ Pernyataan pak Irfan itu mengandung arti ada ketidakpuasan umat Nasrani Gresik terhadap umat Islam dan para pejabatanya.

Juga seperti dituturkan Vitus S.Y. anggota TNI AL beragama Katolik, yang mengatakan bahwa "toleransi di Gresik Driyoreja itu semu. Kelihatannya baik, tapi terkait dengan pendirian gereja-gereja di Driyorejo jelas toleransi itu tidak ada". ${ }^{33}$ Ada faktor rekayasa dalam penolakan itu. Kalau didalami penolakan itu melalui unjuk rasa, nampak jelas bahwa yang demo itu bukan orang perumahan di sini,

\footnotetext{
31 Surat Bupati Gresik yang ditujukan kepada Pengurus Gereja Bethany Indonesia Jalan Mutiara 1.6 Blok 11B/AD No. 16 Kota Baru Driyorejo dan Pengurus Gereja Katolik Santo Gabriel Jalan Raya Giok Kota Baru Driyorejo, Nomor: 450/777/437.77/2010 tanggal 28 Desember 2010, isinya menghentikan pembangunan kedua gereja tersebut, melepas symbol dan label-label pada kedua gereja tersebut dan menghentikan segala bentuk peribadatan/kebaktian pada kedua gereja tersebut.

32 Yohanes Irfan, Wawancara, Gresik 8 Juli 2015.

${ }^{33}$ Vitus S. Y. (anggota TNI AL dari agama Katolik), Wawancara, Gresik 12 Juli 2015.
} 
berarti sudah dipolitisasi". ${ }^{34}$ Martinus Rande menyebut "tidak elok penghentian bangunan gereja itu bagi anak cucu. Artinya, sudah ada benih-benih intoleransi di sini". 35

Pengguna Gereja dari agama Kristen Jawi Wetan, yakni bapak Sutiono, sependapat bahwa "toleransi umat beragama di Gresik menjadi tercoreng dengan adanya penolakan atau penghentian pembangunan tempat ibadah Kristen itu".36 Pendeta Ari Setiorini, pembina agama Kristen Jawi Wetan di Gresik, terkesan kecewa dan merasa toleransi itu nampak tidak seutuhnya. Ia merasa kebebasan beribadah umat Kristen terbatasi. Ia berujar "kami hanya ingin beribadah, bukan untuk makar kepada negara. Kalau kami dipersulit apa artinya kebebasan menjalankan ibadah sebagaimana dalam pasal 29 UUD 1945". 37

Namun, sebagaimana yang telah dikemukakan bahwa berdasarkan asumsi dasar struktural-fungsionalisme, meskipun stabilitas sistem sosial rentan mengalami perubahan yang disebabkan oleh faktor eksternal, tetapi sistem sosial memiliki mekanisme pertahanan dan pengendalian terhadap pengaruh eksternal. Pengendalian sistemik dalam kasus relasi antarumat beragama ini berupa konsensus sosial atau aturan perundangan. Dalam konteks pengendalian relasi antarumat beragama, misalnya, pemerintah Gresik telah mengimplementasikan Peraturan Bersama Menteri (PBM) Menag dan Mendagri No. 8 dan No. 9 Tahun 2006 tentang Pedoman Pelaksanaan Tugas Kepala Daerah dan Wakil Kepala Daerah Dalam Pemeliharaan Kerukunan Umat Beragama. Peraturan ini selain mengatur pelaksanaan tugas Kepala Daerah dan Wakil Kepala Daerah dalam pemeliharaan kerukunan umat beragama juga mengatur pemberdayaan FKUB dan Pendirian Ruman Ibadat. Peraturan Bersama Menteri (PBM) ini telah disosialisasikan secara intensif sejak tahun 2006 dengan harapan masyarakat mulai dari unsur elite hingga masyarakat bawah memahami dan melaksanakan secara normatif isi PBM untuk mengantisipasi tindakan anarkis atas nama agama yang

\footnotetext{
${ }^{34}$ Ibid.

35 Martinus Rande, Wawancara, Driyorejo, Gresik 12 Juli 2015.

36 Sutiono (Pengguna Gereja dari agama Kristen Jawi Wetan), Wawancara, Driyorejo Gresik 12 Juli 2015.

37 Pdt. Ari Setorini (pembina agama Kristen Jawi Wetan di Gresik), Wawancara, Gresik 8 Juli 2015.
} 
muncul sehingga mengganggu ketenangan dan ketenteraman masyarakat sendiri. ${ }^{38}$

Selain Peraturan Bersama Menteri juga diterbitkan Peraturan Bupati (PERBUP) Tentang Kerukunan hidup antarumat beragama yang pada prinsipnya untuk dapat mengimplementasikan PBM dengan mempertimbangkan kekhususnan di daerah masing-masing baik dari segi dukungan daerah, corak politik serta karakteristik budaya masyarakat setempat yang mungkin belum termaktub dalam PBM. Kebupaten Gresik sendiri dalam rangka mengimplementasikan pelaksanaan PBM di daerahnya telah mengeluarkan peraturan Bupati untuk memudahkan tata laksana dan program kerja FKUB di Kabupaten Gresik.

Dengan diimplementasikannya PBM di Kabupaten Gresik, terbentuklah forum FKUB di Gresik. Secara kelembagaan FKUB di Gresik telah ada sejak tahun 2004 FKUB ini kemudian mendapatkan perhatian yang serius dari para tokoh agama dan pemerintah Kabupaten Gresik sejak diberlakukannuya Peraturan Bersama Menteri (PBM) Menag dan Mendagri No. 9 dan No. 8 Tahun 2006 Tentang Pedoman Pelaksanaan Kepala Daerah dan Wakil Kepala Daerah Dalam Pemeliharaan Kerukunan Umat Beragama, maka FKUB Gresik telah membentuk secara formal dengan Surat Keputusan Bupati pada tahun 2007.

Adapun dalam kegiatannya dan program kerjanya, FKUB Gresik telah melaksanakan berbagai sosialisasi atau roadshow PBM mulai dari elemen pemerintahan, birokrasi, tokoh-tokoh agama dan masyarakat, akademisi, pelajaran dan pemuda serta pegiat lintas agama. Sosialisasi ini dilaksanakan mulai tingkat kabupaten, kecamatan, dan desa. Selain, itu FKUB Gresik juga melaksanakan studi banding keluar pulau Jawa, misalnnya ke Sulawesi Utara pada tahun 2010 yang membawa misi untuk mengetahui cara memelihara kerukunan antarumat beragama di Sulawesi Utara.

Melalui mekanisme pengendalian sistem aturan PBM No. 8 dan No. 9 Tahun 2006 dan pembentukan lembaga Forum Kerukunan Umat Beragama, maka berbagai dialog dan kebijakan tentang pendirian rumah Ibadat dapat dimusyawarahkan.

38 M. In'am (Tokoh Muhammadiyah dan Pengurus FKUB Gresik), Wawancara, Gresik 27 Mei 2014. 


\section{Problematika Pendirian Gereja di Perumahan Non-Dinas TNI AL Driyorejo Gresik}

Sebagaimana tersebut di awal bahwa hubungan antarumat beragama yang harmonis di Kabupaten Gresik sering terusik dengan berbagai persoalan keagamaan terutama pendirian rumah ibadat. Demikian halnya dengan pendirian gereja di Perumahan Non-Dinas TNI AL di Kota Baru Driyorejo, Gresik.

Dengan semakin ramainya pemukiman warga di daerah Driyorejo, maka banyak warga Muslim yang membangun masjid secara swadaya sebagai kebutuhan sarana ibadah. Sekitar tahun 2004 sudah ada 23 buah masjid dan musala yang dibangun di lahan fasilitas umum (fasilitas umum). Melihat hal tersebut, umat Kristen dan Katholik yang menjadi penghuni Perumnas Driyorejo juga ingin mendirikan gereja agar tidak perlu ke Surabaya kalau ingin beribadah kebaktian pada hari minggu. Menurut penjelasan Pdt. B. Steven Sitorus, S.Th dan istri Pdm.Ruth Asmina Pasaribu, S.Th sejak tahun 2000 telah melakukan pelayanan dan kebaktian dan Sekolah Minggu dari rumah ke rumah. ${ }^{39}$

Keinginan umat Nasrani tersebut pada awalnya disampaikan kepada Manager Cabang Perum Perumnas Kantor Regional VI Cabang Gresik. Melihat kenyataan bahwa sudah ada rumah ibadat untuk umat Islam dan belum adanya gereja, maka manager Cabang Perum Perumnas Kantor Regional VI Cabang Gresik mengirim surat kepada General Manager Perum Perumnas Regional VI di Surabaya dengan nomor Reg.VI/Cab.Grs/403/09/2005 tanggal 7 September 2005 perihal Permohonan Lahan fasum untuk sarana ibadah. Isi surat tersebut adalah permohonan pemakaian lahan fasum di Blok $12 \mathrm{H}$ yang akan digunakan oleh delapan gereja dengan pembagian tiga denominasi, yaitu Protestan, Karismatik dan Gereja Bethel Indonesia (AGAPE). Surat ini kemudian direspons oleh General Manager dengan surat balasan nomor Reg.VI/Cab.Grs/403/09/2005 tanggal 13 Oktober 2005 yang menyatakan bahwa karena di Perumnas belum ada sarana ibadat umat non-Muslim, maka General Manager menyetujui penyerahan tanah tersebut untuk kepentingan tempat ibadat umat Kristen dan Katolik dengan ketentuan bahwa peruntukan dan penggunaan lahan untuk pembangunan gereja tersebut

39 Pdt. B. Steven Sitorus, S.Th. dalam http://stevensitorus.blogspot.com/2013 /08/sejarahgpdi-pemulihan-kbd.html 
dilaksanakan berdasarkan persetujuan Bupati Kepala Daerah Kabupaten Gresik.40

Sejalan dengan surat General Manager Perum Perumnas tersebut, Sekretaris Daerah Gresik juga telah mengirim surat kepada Manager Cabang Perum Perumnas di Driyoreja yang isinya antara lain: No.450/809/403.74/2005 tanggal 20 Oktober 2005 perihal Pemberitahuan Pemakaian Fasum. Surat ini menjawab surat dari Manager Cabang Perum Perumnas Driyorejo No. Reg.VI/Cab.Grs/806/09/2005 tanggal 17 September 2005 perihal Pemberitahuan Pemakaian Lahan Fasum untuk tempat ibadat. Dalam surat ini diterangkan bahwa: 1) bentuk kegiatan fisik yang ada di atas tanah fasum harus disesuaikan pada site plan yang sudah ada sesuai peraturan perundang-undangan yang berlaku; 2) seyogianya lahan fasum untuk keperluan tempat ibadat diserahkan dulu ke pemerintah daerah melalui tim verifikasi fasos/fasum; dan 3) Pemda Kab. Gresik yang akan mengatur peruntukannya. Manager Perum Perumnas Cab. Gresik juga menulis surat kepada Bupati Gresik No. Reg.VI/809/10 /2005 tanggal 31 Oktober 2005 perihal persetujuan peruntukan dan penggunaan lahan untuk pembangunan gereja. ${ }^{41}$

Selanjutnya sampai pada tahun 2007 belum ada penyerahan secara resmi lahan fasum/fasos tersebut kepada Pemerintah Kabupaten Gresik, namun pada tanggal 10 Oktober 2007 Komandan Pangkalan Utama TNI AL V mengeluarkan surat dengan Nomor: B.14120/03/14/Lant-V kepada Bupati Gresik yang isinya:

1. Menunjuk Surat dari Gereja Bethany Indonesia Nomor: 09/GBIJD/VIII/2007 tanggal 13 Agustus 2007 Perihal Permohonan Perizinan;

2. Surat Gereja Katolik Paroki Santo Yusup Nomor: 006/PANPEMB/KPP/xi/ 2005 tanggal 09 Desember 2004 Perihal Permohonan Lahan Ibadah (Gereja) Umat Katolik;

3. Surat Gereja Katolik Paroki Santo Yusuf Nomor: 008/PANPEMB/XI/2005, tanggal 14 November 2005 perihal Permohonan Surat Dinas untuk mendapatkan Surat Persetujuan Lahan Tempat Ibadah;

\footnotetext{
40 Titik Suwariyati, "Studi Kasus Pembangunan Gereja Kristen Bethany Indonesia dan Gereja Katolik Santo Gabriel di Perumnas Kota Baru Driyorejo Kecamatan Driyorejo Kabupaten Gresik", Haidlor Ali Ahmad (ed.), Hubungan Umat Beragama: Studi Kasus Penutupan/Perselisiban Rumah Ibadat (Jakarta: Kementerian Agama RI, Badan Litbang dan Diklat Puslitbang Kehidupan Keagamaan, 2012), 144.

${ }^{41}$ Ibid., 145.
} 
4. Surat dari Perum Perumnas Regional VI cabang Gresik Nomor Reg.VII/Cab Grs/806/09/2005 tanggal 07 September 2005 perihal Pemberitahuan Pemakaian Lahan untuk Sarana Ibadah;

5. Surat dari Pemerintah Kabupaten Gresik Nomor 450/809/403.74 /2005 tanggal 20 Oktober 2005 perihal Pemberitahuan Pemakaian Fasum. ${ }^{42}$

Dengan memperhatikan surat-surat tersebut di atas Lantamal V mengizinkan kepada Panitia Pembangunan Gereja Kristen dan Katolik untuk mendirikan Gereja di lahan Perumahan TNI AL Driyorejo masing-masing seluas $500 \mathrm{~m} 2$ dan areal parkir bersama seluas $420 \mathrm{~m} 2$ dari lahan fasum seluas $1.420 \mathrm{~m} 2$. Surat tersebut disertai gambar denah lahan dan tembusan surat disampaikan kepada 10 pihak antara lain: Arena Danlantamal V, Aslog Danlantamal V, Aspers Danlantamal V, Kadisfaslan Lantamal V, Bappeda Kabupaten Gresik, Kepala Dinas PU Kabupaten Grsik, Camat Driyorejo, Direktur PT REI Jatim, Panitia Pembanguna Gereja Kristen dan Panitia Pembanguna Gerja Katolik.43

Sikap Gereja Kristen Bethany dan Katolik Santo Gabriel terhadap surat Dan Lantamal V tersebut:

1. Gereja Bethany Indonesia membuat surat yang ditujukan kepada Ketua RT 10 Giok, Ketua RT 22 Giok, Ketua RT 23 Giok, Ketua RT 24 Giok, dan Ketua RT 25 Giok, dengan maksud untuk memberitahukan atau menyosialisasikan surat persetujuan pembangunan Gereja Bethany Indonesia di tanah fasum Perumahan TNI AL Wilayah Jl. Giok Kota Baru Driyorejo Gresik;

2. Panitia Pembangunan Gereja Bethany Indonesia untuk melakukan pembangunan sampai bangunan fisik gereja itu selesai. Bangunan itu tidak disertai simbol-simbol yang khusus yang menunjukkan bahwa bangunan itu tempat ibadah, jadi seperti rumah biasa;

3. Masyarakat sekitar tidak protes karena mereka adalah warga angkatan laut itu sendiri ${ }^{4}$, demikian menurut seorang penyuluh Agama pada KUA setempat;

42 Ibid.

43 Surat Dan Lantamal V nomor: B/141-20/03/14/Lant V tertanggal 10 Oktober 2007 yang ditujukan kepada Bupati Gresik

${ }^{44}$ Najib (Penyuluh Agama Kecamatan Driyorejo), Wawancara, Gresik 12 Mei 2014. 
4. Panitia Pembangunan Gereja Katolik Santo Gabriel berniat memulai membangun gereja dengan mengadakan upacara peletakan batu pertama;

5. Masyarakat pun mulai resah, bahkan kemudian juga mempertanyakan status Gereja Kristen Bethany Indonesia yang sudah berwujud bangunan dan sudah dipergunakan untuk kebaktian.

Seiring perjalanan waktu, terkait Rumah Ibadat, tanggal 21 Maret 2006 telah disahkan Peraturan Bersama Menteri Agama dan Menteri Dalam Negeri Nomor: 9 dan 8 Tahun 2006 (PBM 2006) tentang Pedoman Pelaksanaan Tugas Kepala Daerah/Wakil Kepala Daerah dalam Pemeliharaan Kerukunan Umat Beragama, Pemberdayaan Forum Kerukunan Umat Beragama, dan Pendirian Rumah Ibadat. ${ }^{45}$ Dalam pasal 14 PBM 2006 ditegaskan bahwa: (1). Pendirian rumah Ibadat harus memenuhi persyaratan administratif dan persyaratan teknis bangunan gedung, (2). Selain memenuhi persyaratan sebagaimana tersebut dalam ayat (1) pendirian rumah ibadat harus memenuhi persyaratan khusus meliputi; daftar nama dan KTP pengguna tempat ibadah minimal 90 0rang yang disahkan oleh pejabat setempat sesuai tingkat batas wilayah; dukungan masyarakat setempat paling sedikit 60 orang yang disahkan oleh lurah/Kepala desa, rekomendasi tertulis dari Kepala Kantor Departemen Agama Kabupaten/Kota setempat dan Rekomendasi dari FKUB Kabupaten/Kota setempat. ${ }^{46}$

PBM 2006 ini sudah disosialisasikan beberapa kali dan masyarakat paham, akan tetapi panitia pembangunan Gereja tidak menghiraukan. Hal ini dibuktikan dengan respons dari Panitia Pembangunan Gereja Kristen Bethany Indonesia yang mengirim surat kepada Bupati Gresik dengan nomor: 57/GBI-JP/VII/2008 tanggal 13 Juli 2008 perihal Permohonan Izin Mendirikan Bangunan. Surat ini mendapat jawaban dari Bupati Gresik dengan surat nomor: 050/679/403.71/2008 tanggal 24 Sept 2008. Inti dari isi surat tersebut adalah: 1) Berdasarkan pengesahan site plan tanggal 6 Agustus 2004 Nomor: 503.648/3671/403.51.3/2004 lokasi lahan tersebut peruntukannya

\footnotetext{
${ }^{45}$ M. In'am (Tokoh Muhammadiyah Gresik), Wawancara, Gresik 23 Mei 2014.

46 Peraturan Bersama Menteri Agama dan Menteri Dalam Negeri RI Nomor 9 dan 8 tahun 2006 tentang Pedoman Pelaksanaan Tugas Kepala Daerah/Wakil Kepala Daerah Dalam Pemeliharaan Kerukunan Umat Badan Kesatuan Bangsa dan Politik Jawa Timur Beragama. Pemberdayaan Forum Kerukunan Umat Beragama, Dan Pendirian Rumah Ibadat, Bab V pasal 18.
} 
adalah sebagai pertokoan; 2) Lahan belum diserahkan kepada Pemeritah Kab. Gresik, sehingga masih menjadi kewenangan pihak pengembang; dan 3) Hendaknya pihak pengembang menyerahkan terlebih dahulu fasos-fasum kepada Pemerintah Kab. Gresik. ${ }^{47}$

Selanjutnya pada tanggal 12 November 2008, Tim Verifikasi Uji Faktual FKUB Kabupaten Gresik melakukan pemeriksaan terhadap persyaratan permohonan Gereja Bethany Indonesia menghasilkan kesimpulan bahwa:

a. Dari 97 daftar calon pengguna rumah ibadah tersebut, hanya 23 orang yang sesuai dengan KTP beralamat di Petiken (sekitar tempat ibadah) di Driyorejo Gresik;

b. Dari jumlah 60 (enam puluh) nama warga yang memberikan persetujuan hanya 14 orang saja. ${ }^{48}$

Sementara itu salah seorang warga di sekitar tempat pendirian gereja tersebut merasa ditipu oleh pejabat RW setempat setelah mengetahui bahwa sebenarnya dia tidak tahu apabila namanya dimasukkan dalam daftar orang yang menyetujui pendirian gereja setempat. Konon ketua RW mau memberikan nama warganya karena dijanjikan oleh seseorang yang akan memberikan fasilitas Taman Warga, namun sampai saat ini Taman yang dijanjikan juga belum terealisir. ${ }^{49}$

Berdasarkan hasil Verifikasi tersebut, FKUB Kabupaten Gresik mengeluarkan surat rekomendasi Nomor: 12/FKUB.GRS/11/2008, tertanggal 12 November 2008, yang isinya tidak menyetujui atas permohonan gereja Bethany Indonesia karena tidak memenuhi syarat sebagaimana dalam Peraturan Bersama Menteri Agama dan Menteri Dalam Negeri RI Nomor 9 dan 8 tahun 2006, pasal 14 ayat (2) yaitu daftar nama pengguna diserta Kartu Tanda Penduduk (KTP) pengguna sejumlah 90 (Sembilan puluh) orang yang disahkan oleh pejabat setempat dan dukungan masyarakat setempat paling sedikit 60

\footnotetext{
${ }^{47}$ Surat jawaban Bupati Gresik atas Permohonan izin Pendirian Rumah Ibadat dari Panitia Pembangunan Gereja Bethany Indonesia. Surat jawaban itu bermaksud agar Panitia menyesuaikan dengan aturan yang ada.

${ }^{48}$ Yarham (Pengurus FKUB Kabupaten Gresik), Wawancara, Gresik 29 Mei 2014.

${ }^{49} \mathrm{H}$. Wagino (Warga Perumahan Non-Dinas TNI AL), Wawancara, Gresik $15 \mathrm{Mei}$ 2014.
} 
(enam puluh) orang yang disahkan oleh lurah/Kepala Desa setempat. ${ }^{50}$

Hasil verifikasi FKUB ini tidak dihiraukan oleh panitia pembangunan gereja, dan bahkan dikeluarkan surat atas nama RW VII Perumnas Kota Baru Driyorejo, Desa Randegansari Kec. Driyorejo No. 02/KBD/23/III/2009 tanggal 23 Maret 2009 yang ditandatangani Ketua RW VIII Desa Randegansari dan diketahui oleh Kepala Desa Randegansari yang isinya mereka menyetujui pembangunan gereja tersebut. Surat ini dilampiri tanda tangan warga sebanyak 23 lembar. ${ }^{51}$ Dan Panitia Pembangunan gereja Kristen Bethany maupun gereja Kaholik Santo Gabriel tetap melanjutkan pembangunannya dengan alasan sudah mendapat izin dari Danlantamal (Komandan Pangkalan Utama Angkatan Laut).

Pemerintah Kabupaten Gresik melalui Kepala Kantor Kesatuan Bangsa, Politik dan Perlindungan Masyarakat Kabupaten Gresik, telah melakukan teguran kepada Panitia agar tidak melanjutkan pembangunan tersebut dengan surat nomor: 450/630/437.73/2009, tertanggal 30 September 2009 dan surat nomor: 450/676/437.77/2009, tenggal 16 Oktober 2009. Namun pada tanggal 30 Maret 2010, Komando Armada RI Kawasan Timur Pangkalan Utama V (Koarmatim Lantamal V), mengirim surat yang ditujukan kepada Kepala Kantor Kesatuyan Bangsa dan Perlindungan Masyarakat (Kesbanglinmas) Kabupaten Gresik dengan nomor: B/14-20/03/14/LAN V, perihal Pembangunan Gereja Bethany Indonesia dan Gereja Katolik di Perumahan Driyoreja, yang isinya:

1. Pembangunan dua buah Rumah Ibadat di Perumahan Non-Dinas TNI AL tersebut telah sesuai dengan Peraturan Bersama Menteri Agama dan Menteri Dalam Negeri RI nomor 9 dan Nomor 8, yaitu telah mendapat dukungan masyarakat sebanyak 60 rang, dan memenuhi 90 orang pengguna;

2. Pembangunan dua buah Rumah Ibadat di Perumahan Non-Dinas TNI AL tersebut akan tetap dilaksanakan mengingat pembangunan tersebut bertujuan untuk meningkatkan ketakwaan anggota militer/PNS TNI AL dan warga sekitarnya. ${ }^{52}$

\footnotetext{
50 Catatan Badan Kesatuan Bangsa Provinsi Jawa Timur, tentang kronologi pendirian Gereja Bethany Indonesia dan gereja Santo Gabriel Gresik. Surat disampaikan kepada Kesbanglinmas Kabupaten Gresik.

${ }^{51}$ Suwariyati, "Studi Kasus", 150.

52 Surat Koarmatim Lantamal V ini ditanda tangani oleh Komandan Pangkalan Utama TNI AL V Brigadir Jendral TNI (Mar) Halim A. Hermanto, SH dengan 13
} 
Berdasar surat Komandan Armatim Lantamal V tersebut, Panitia Pembangunan Gereja tetap dilaksanakan baik Gereja Bethany maupun Katolik. Kondisi ini menimbulkan keresahan warga. Para pemuda dan tokoh masyarakat Driyorejo dan sekitarnya, ada yang berkeinginan untuk merusak gereja tersebut. Namun niatan tersebut dapat diredam oleh salah satu tokoh masyarakat yaitu H. Sururi, tokoh muda yang cukup berpengaruh dan pernah menjadi anggota DPRD Kabupaten Gresik. Akhirnya pada tanggal 10 Februari 2010 atas nama Warga Muslim Perumahan Kota Baru Driyorejo (KBD) menulis surat kepada Bupati Gresik yang isinya keberatan dengan adanya pembangunan Gereja di Perumnas KBD. Ditegaskan bahwa jika pemerintah daerah tidak mengambil tindakan tegas untuk menghentikan pembangunan gereja tersebut, dikhawatirkan akan terjadi perusakan oleh masyarakat. ${ }^{53}$

Reaksi masyarakat Gresik dan umat Islam Driyorejo pada khususnya berpijak pada aturan yang ada bahwa pendirian gerejagereja di Perumahan Non-Dinas TNI AL tersebut dianggap telah melanggar aturan perundangan yang ada, yakni:

1. Pembangunan Gereja Bethany Indonesia dan Katolik Santo Gabriel di fasilitas umum Perumahan Non-Dinas TNI AL melibatkan unsur kekuasaan dari oknum TNI Angkatan Laut. Sementara pembangunan rumah ibadat tersebut dinilai tidak sesuai dengan aturan yuridis formal pendirian rumah ibadat. Hal inilah yang menjadikan masyarakat Gresik menolak pembangunan gereja itu dilanjutkan, karena sikap itu dianggap tidak benar. ${ }^{54}$

2. Pembangunan rumah ibadat tersebut dianggap menyalahi aturan di antaranya:

a. Surat Bupati Gresik Nomor: 450/809/403.74/2005, tanggal 20 Oktober 2005, yang ditujukan Perum Perumnas Kantor Regional IV Cabang Gresik, yang isinya menjelaskan bahwa seharusnya lahan fasum untuk tempat ibadah seharusnya diserahkan dahulu

tembusan yang disampaikan antara lain kepada: Kasal, Pangarmatim, Asintel, Aspers, Aslog Danlantamal V, Kadisfaslan Lantamal V, Bupati Gresik, Kepala Kantor Wilayah Kemenag Jawa Timur, Ketua FKUB Kabupaten Gresik, Ketua Panitia Pembangunan Gereja Bethany dan Katolik di Driyorejo, Camat Dryorejo dan Kepala Desa Mulung.

${ }^{53}$ Suwariyati, "Studi Kasus", 10.

${ }^{54}$ K.H. Afif Maksum (Ketua FKUB Kabupaten Gresik), Wawancara, Gresik 27 Mei 2015. 
kepada Pemerintah Daerah melalui tim Verifikasi fasilitas sosial/fasilitas umum;

b. Surat Rekomendasi FKUB Kabupaten Gresik Nomor; 12/FKUB.GRS/I/ 2008, tanggal 12 November 2008, yang menyatakan tidak menyetujui atas permohonan pembangunan gereja Bethany Indonesia karena tidak sesuai dengan Peraturan Bersama Menteri Agama dan Menteri Dalam Negeri Nomor 9 dan 8 tahun 2006 pasal 14 ayat (2);

c. Protes masyarakat Muslim di Perumnas Driyorejo Kota Baru yang selanjutnya dituangkan dalam bentuk surat kepada Bupati Gresik pada tanggal 10 Februari 2010 yang berisi keberatan dengan adanya Pembanungan Gereja di Perumnas KBD, jika pemerintah daerah tidak mengambil tindakan tegas untuk menghentikan pembangunan gereja tersebut, dikhawatirkan akan terjadi pengrusakan.

d. Surat Badan Penanaman Modal dan Perizinan Kabupaten Gresik Nomor: 503/582/437.77/2010 dan 503/583/437.77/2010 tanggal 22 November 2010 perihal penghendian pembangunan Gereja Bethany Indonesia dan Gereja Katolik Santo Gabriel;

e. Surat Kepala Kantor Kesbangpol Linmas Kabupaten Gresik kepada Komandan Pangkalan Utama TNI AL V Nomor: 405/105/437.77/2010 yang isinya penghentian semua jenis aktivitas pembanguna gereja di perumahan Non-Dinas TNI AL Driyorejo;

f. Surat Bupati Gresik Nomor: 450/777/437.77/2010, tertanggal 28 Desember 2010 yang ditujukan kepada Pengurus Gereja Bethany Indonesia dan Gereja Katolik Santo Gabriel yang isinya: a). agar segera menghentikan seluruh kegiatan pembangunan Gereja Kristen Bethany Indonesia dan Gereja Katolik Santo Gabriel; b). segera melepas semua simbol atau label yang ada pada kedua gereja tersebut; dan c). menghentikan segala bentuk kegiatan peribadatan/kebaktian pada kedua gereja tersebut.

Selain itu, pendirian gereja-gereja ini juga menimbulkan persoalan sosial lainnya, yakni munculnya reaksi ketersinggungan masyarakat sekitar aktivitas gereja-gereja tersebut yang dinilai sangat mengganggu serta tidak memiliki etika sopan santun. Sikap umat Nasrani terutama jemaah yang datang dari luar wilayah tempat kebaktian dinilai tidak bersahabat, menyinggung perasaan, mengandalkan pejabat serta mengganggu lingkungan. Bahkan pejabat tinggi di Kabupaten Gresik 
menyatakan mensinyalir bahwa sikap penganut agama Nasrani itulah yang menjadi salah satu faktor penolakan pembangunan gereja di Gresik. Hal ini sebagaimana diungkapkan oleh disampaikan Wakil Bupati Gresik bahwa salah satu faktor penolakan terhadap keberadaan Gereja di daerah perumahan Non-Dinas AL di Driyorejo tersebut disebabkan sikap arogansi, tidak santun, dan tidak ramah dengan masyarakat sekitarnya. Hal ini misalnya dapat dilihat dari cara mengendarai sepeda motor atau mobil yang dinilai sangat mengganggu ketenangan dan kenyamanan situasi terutama pada saatsaat masyarakat menjalankan ibadah. Selain itu mereka juga terkesan tidak ramah dengan warga masyarakat sekitar. Sikap sosial yang eksklusif dari warga Kristen di lingkungan perumahan inilah yang kemudian menyulut demo yang dilakukan oleh kelompok pemuda, seperti Anshor, IPNU, dan tokoh-tokoh masyarakat. Intinya, mereka ingin menunjukkan bahwa mereka tidak suka dengan adanya tempat ibadat yang tidak sesuai aturan dan aturan yang ada diinjak-injak, serta tidak menghormati lingkungannya. ${ }^{55}$

Demikian juga sikap yang ditunjukkan oleh para tokoh agama di Gresik kalangan masyarakat yang berhubungan langsung dengan keberadaan gereja di perumahan Non-Dinas TNI AL di Driyorejo. Menurut mereka, masyarakat Gresik menolak karena alasan regulasi dan arogansi panitia pembangunan gereja dari Lantamal V. Menurut mereka, panitia terkesan mengandalkan pejabat tertentu di lingkungan Angkatan Laut, meskipun sudah mengetahui bahwa pembangunan tempat ibadah itu ada prasyarat yang harus dipenuhi dan dipatuhi. Sikap mereka dinilai sangat menyinggung perasaan masyarakat Gresik yang tingkat fanatisme agamanya cukup tinggi. Apalagi sikap mereka yang tidak mau berkompromi dengan masyarakat atau pemerintah setempat. ${ }^{56}$

Tokoh Agama yang sekaligus penggerak pemuda H. Sururi menyatakan bahwa mereka menamakan gereja tersebut dengan menyandarkan instansi pemerintah dengan nama Gereja Maritim. Penggunaan nama gereja ini dinilai tidak benar, mengingat gereja ini didirikan di atas tanah fasilitas umum, bukan fasilitas dinas. Penggunaan nama gereja yang disandarkan pada instansi militer tersebut diduga terkait keberadaan gereja yang dekat dengan perumahan angkatan laut. Dengan cara ini masyarakat di sekitar perumahan tersebut tidak berani

${ }^{55}$ H. Moh. Qosim (Wakil Bupati Gresik), Wawancara, Gresik 16 Mei 2015.

${ }^{56}$ KH. Afif Ma'sum, Wawancara, Gresik 27 Mei 2014. 
protes. Apalagi hal ini ditunjang belum adanya penyerahan fasilitas tersebut kepada Pemerintah Kabupaten Gresik. ${ }^{57}$

Pelanggaran terhadap aturan perundangan dan ketersinggungan sosial inilah yang menimbulkan keresahan masyarakat Gresik, baik para tokoh agama, masyarakat dan umat Muslim pada umumnya. Kondisi hubungan antarumat beragama yang awalnya kondusif menjadi terusik dengan pelanggaran tersebut. Umat Muslim Gresik yang mayoritas agamis tidak ingin ada sekelompok umat yang tidak mau diatur dalam kehidupan bermasyarakat dan berbangsa.

\section{Analisis Problematika Pendirian Gereja}

Sebagaimana diungkapkan oleh Parsons, bahwa keseimbangan sistemik (equilibrium systemic) memiliki prasyarat-prasyarat fungsional (requisite functionalism), yakni:

1) Sistem sosial harus terstuktur (tertata) sehingga dapat beroperasi dalam hubungan yang harmonis dengan sisten lain.

2) Untuk menjaga kelangsungan hidupnya sistem sosial harus mendapatkan dukungan dari sistem lain.

3) Sistem sosial harus mampu memenuhi kebutuhan aktornya dalam proporsi yang signifikan.

4) Sistem sosial harus mampu melahirkan partisipasi yang memadai dari para anggotanya.

5) Sistem sosial harus mampu mengendalikan perilaku yang berpotensi menggangu.

6) Bila konflik akan menimbulkan kekacauan maka harus bisa dikendalikan.

7) Sistem sosial memerlukan bahasa.

Keseimbangan sistemik (equilibrium systemic) dapat terjadi jika prasyarat-prasyarat fungsional tersebut terpenuhi. Dengan terjadinya keresahan masyarakat Gresik terkait dengan pendirian gereja di wilayah Driyorejo tersebut menunjukkan bahwa keharmonisan relasi antarumat beragama (integration) masyarakat Gresik tengah terganggu. Oleh karena itu sesuai dengan rumusan prasyarat fungsional suatu sistem, yakni butir ke 5 dan 6, bahwa karakteristik sistem itu harus dapat mengendalikan perilaku yang berpotensi menggangu. Bila konflik menimbulkan kekacauan harus bisa dikendalikan. Mekanisme pengendalian gangguan atau konflik ini untuk menstabilisir keadaan,

57 Sururi (agamawan sekaligus penggerak pemuda), Wawancara, Gresik 12 April 2014. 
yakni mulai dari upaya unjuk rasa hingga melalui mekanisme regulasi yang berlaku.

Upaya ini terutama diarahkan untuk menemukan titik temu dari akar permasalahannya. Karena dalam hal ini, pihak pendiri gerejagereja yang ada di perumahan Non-Dinas TNI AL Driyorejo bersikukuh bahwa mereka juga telah menjalankan prosedur perizinan. Mereka hanya ingin memenuhi kebutuhan hidup sebagai umat beragama dengan memiliki tempat ibadah tersendiri, sebagaimana umat Islam yang juga sudah memiliki masjid. Bahkan sudah ada 24 masjid dan musala yang dibangun di lahan fasum.

Keinginan itulah yang mendorong umat Nasrani baik yang Katolik maupun Kristen. Maka mereka menyampaikan keinginan tersebut kepada Manager Cabang Perum Perumnas Kantor Regional VI Cabang Gresik. Melihat kenyataan bahwa memang belum ada gereja di wilayah dimaksud, maka Manajer Cabang Perum Perumnas Kantor Regional VI Cabang Gresik mengirim surat kepada General Manager Perum Perumnas Regional VI di Surabaya dengan nomor Reg.VI/Cab.Grs/403/09/2005 tanggal 7 September 2005 perihal Permohonan lahan fasum untuk sarana ibadah. Isi surat tersebut adalah permohonan pemakaian lahan fasum di Blok $12 \mathrm{H}$, untuk digunakan oleh delapan gereja dengan pembagian tiga denominasi, yaitu: Protestan, Karismatik dan Gereja Bethel Indonesia (AGAPE). Surat ini kemudian direspons oleh General Manager Perum Perumnas dengan surat balasan nomor Reg.VI/Cab.Grs/403/09/2005 tanggal 13 Oktober 2005 yang menyatakan bahwa karena di Perumnas belum ada sarana ibadat umat non-Muslim. General Manager menyetujui penyerahan tanah tersebut untuk kepentingan tempat ibadat umat Kristen dan Katolik dengan ketentuan bahwa peruntukan dan penggunaan lahan untuk pembangunan gereja tersebut dilaksanakan berdasarkan persetujuan Bupati Kepala Daerah Kabupaten Gresik. ${ }^{58}$

Surat General manajer Perum Pemnas tersebut sejalan dengan pedoman penggunaan fasum antara lain sebagaimana isi surat Sekretaris Daerah Kabupaten Gresik yaitu: 1) bentuk kegiatan fisik yang ada di atas tanah fasum harus disesuaikan pada site plan yang sudah ada sesuai peraturan perundang-undangan yang berlaku; 2) seyogianya lahan fasum untuk keperluan tempat ibadat diserahkan dulu ke pemerintah daerah melalui tim verifikasi fasos/fasum; dan 3) Pemda Kab. Gresik yang akan mengatur peruntukannya.

${ }^{58}$ Suwariyati, "Studi Kasus", 14. 
Sampai tahun 2007 belum ada penyerahan fasum/fasos kepada Pemerintah Kabupaten Gresik, tetapi Pangkalan TNI Angkatan Laut sudah membuat surat kepada Kabupaten Gresik yang isinya mengizinkan kepada Panitia Pembangunan Gereja Kristen dan Katolik untuk mendirikan Gereja di lahan Perumahan TNI AL Driyorejo masing-masing seluas $500 \mathrm{~m} 2$ dan areal parkir bersama seluas $420 \mathrm{~m} 2$ dari lahan fasum seluas $1.420 \mathrm{~m} 2$.

Menindaklanjuti surat izin Dan Lantamal tersebut, Panitia Pembangunan Gereja Bethany Indonesia dan Gereja Katolik Santo Yusuf segera melakukan tindakan aksi, di mana Gereja Bethany Indonesia membuat surat edaran kepada pengurus RT-RW setempat dan kemudian melaksanakan pembangunan dan hampir selesai bahkan untuk gereja Bethany Indonesia sudah digunakan kebaktian.

Dengan beberapa fakta ini, penyelesaian pendirian rumah ibadat di Perumahan Non-Dinas Driyorejo Gresik ini memang tidak mudah. Hal ini selain menyangkut masalah aturan perundangan juga disinyalir adanya pelanggaran hak asasi menyangkut kebebasan umat beragama dalam menjalankan ibadahnya. Hal ini sebagaimana diatur dalam pasal 29 ayat (2) Undang -Undang Dasar Negara RI 1945: Negara menjamin kemerdekaan tiap-tiap penduduk untuk memeluk agamanya masing-masing dan untuk beribadat menurut agamanya dan kepercayaannya itu. ${ }^{59}$

Sebagian pihak malah berpendapat bahwa aturan perundangan yang mengatur tentang pendirian rumah ibadat di PBM No. 8 dan No. 9 Tahun 2006 itu tidak sesuai dengan kebebasan umat beragama dalam menjalankan peribadatannya sesuai dengan agama dan kepercayaannya. SETARA Institut menyatakan bahwa ... "PBM mengandung cacat konstitusional karena bertentangan dengan normanorma jaminan kebebasan beragama/berkeyakinan yang ada dalam Konstitusi RI. PBM sejak awal dimaksudkan dan ditujukan dalam rangka membatasi kebebasan kelompok-kelompok lain dalam mendirikan rumah ibadah, sehingga nyata dalam implementasinya PBM ini melahirkan diskriminasi terhadap kelompok minoritas". ${ }^{60}$ Bentuk diskriminasi dan tindakan yang tidak tepat dari pelaksanaan PBM tersebut tergambar antara lain:

${ }^{59}$ Undang-Undang Dasar Negara RI 1945, BAB XI AGAMA, Pasal 29

${ }^{60}$ SETARA Institut, Pernyataan Pers, No.08/Ket./HD/PP/IX/2010, tanggal 2309-2010 Legal Review terhadap Peraturan Bersama Menteri Agama dan Menteri Dalam Negeri No. 9/2006, No. 8/2006, lihat: org/id/content/legal-review-terhadapperaturan-bersama-menteri-agama-dan-menteri-dalam-negeri-no-92006-no-8 
1. Negara ikut campur dalam urusan peribadatan. Pertimbangan kuantitatif jemaah dalam pendirian rumah ibadat;

2. PBM hakikatnya adalah unenforceable. Hal ini terbukti seluruh tindakan persekusi yang berhubungan dengan rumah ibadat semuanya berdalih karena adanya pelanggaran terhadap PBM.

3. Kinerja FKUB didasarkan pada paradigma mayoritas dan minoritas kuantitas jumlah jemaah, bukan pada hakikat hak beribadat yang melekat pada setiap warga negara.

4. PBM tidak memiliki landasan legal pada peraturan perundangundangan yang ada di atasnya. Dari 15 produk hukum yang menjadi landasan tidak memberikan landasan yang legitimate pembentukan PBM.

5. PBM ini dipastikan dan telah gagal mewujudkan tujuan pembentukannya, yakni menciptakan kerukunan umat beragama

6. SETARA Institute merekomendasikan agar Pemerintah merevisi Peraturan Bersama Menteri Agama dan Menteri Dalam Negeri No. 9/2006, No. 8/2006.

Demikian juga The Indonesian Legal Resource Center (ILRC) dalam Buku Saku untuk Kebebasan Beragama, yang berjudul Memahami Kebijakan Rumah Ibadat, juga mengemukakan bahwa menurut catatan ILRC, dasar hukum pembentukan aturan rumah ibadah tidak kuat karena bertentangan dengan aturan hukum yang lebih tinggi khususnya UU Nomor 10 Tahun 2004 tentang Pembentukan Peraturan Perundang-Undangan. Kemudian substansi aturan-aturan rumah ibadah sangat birokratis untuk memperoleh izinnya dan ada kecenderungan menghilangkan hak individu/kolektif untuk beribadah dan berkumpul. ${ }^{61}$

Berdasarkan analisis terhadap aturan perundangan peraturan bersama tidak termasuk di dalam hierarki dan jenis peraturan perundang-undangan dan pembentukannya tidak diperintahkan secara jelas dan eksplisit oleh aturan yang lebih tinggi, baik UU/Perpu, PP maupun Kepres (Pasal 7 ayat (1) dan (4) UU Nomor 10 Tahun 2004). Kemudian, karena pendirian rumah ibadah merupakan bagian dari manifestasi keagamaan yang juga merupakan bagian HAM, maka pengaturannya harus dengan UU sesuai dengan perintah pasal 8 huruf a UU Nomor 4 Tahun 2004.62

61 Siti Aminah dan Uli Parulian Sihombing, Memahami Kebijakan Rumah Ibadah (Jakarta: The Indonesian Legal Resource Center (ILRC), 2010), 7.

62 Ibid., 9. 
Sementara ada yang menyatakan bahwa apabila PBM tahun 2006 atau Perber 2006 tidak dicabut akan menimbulkan banyak masalah. Problem struktural pengaturan secara administratif di mana harus memenuhi persyaratan administratif dan ketika terjadi penolakan dari warga, pemerintah pada praktiknya ingin lepas tangan dan membiarkan panitia berhadap-hadapan dengan masyarakat. Dalam situasi semacam itu, jangan mereka masih harus melewati beberapa pintu lain, yakni izin lurah/kepala desa, FKUB, dan Kementerian Agama. Seperti pemerintah daerah, dalam banyak kasus mereka sering pula tunduk pada desakan massa. ${ }^{63}$

Sementara, Sekretaris Eksekutif Komisi Hubungan Antaragama dan Kepercayaan Konferensi Waligereja Indonesia (Komisi HAK KWI), Romo Antonius Benny Susetyo mengatakan Indonesia membutuhkan regulasi yang menjamin kebebasan beragama sebab rancangan undang-undang kerukunan tidak memberi jawaban terhadap jaminan konstitusi. Dikatakan bahwa "Kerukunan buah yang alamiah tidak usah diatur karena kalau diatur menciptakan potensi konflik. Yang dibutuhkan regulasi yang mengatur jaminan kebebasan beragama". ${ }^{64}$ Ungkapan itu menandakan bahwa PBM yang memuat aturan agar terjadi kerukunan termasuk mengatur tentang pendirian rumah ibadah tidak perlu yang diperlukan adalah regulasi tentang kebebasan.

Namun terlepas dari perdebatan tentang keberadaan PBM Tahun 2006, yang perlu digarisbawahi, bahwa kebebasan warga negara dalam menjalankan hak-haknya bukan berarti bebas tak terbatas, tetapi kebebasan yang bertanggung jawab. Hal ini sebagaimana ditegaskan dalam pasal $28 \mathrm{~J}$ ayat (2) sebagai berikut:

“...Dalam menjalankan hak dan kebebasannya, setiap orang wajib tunduk kepada pembatasan yang ditetapkan oleh undang-undang dengan maksud semata-mata untuk menjamin pengakuan atau penghormatan atas hak dan kebebasan orang lain dan untuk memenuhi tuntutan yang adil sesuai dengan pertimbangan moral, nilai-nilai agama, keamanan dan ketertiban umum dalam suatu masyarakat demokratis". ${ }^{65}$

\footnotetext{
63 http://hukum.kompasiana.com/2011/12/13/menggugat-pencabutan-perber-2menteri/

64 Antonius Beny Susetyo, dalam http://www.antaranews.com/berita/302100 /indonesia-perlu-regulasi-jaminan-kebebasan-beragama

${ }^{65}$ Pasal $28 \mathrm{~J}$ ayat (2) ini merupakan pasal tambahan dari hasil revisi ke terakhir. Pasal ini merupakan pasal yang mengatur bahwa kebebasan menjalan hak asasi manusia
} 
Di samping itu perlu dijelaskan bahwa kebebasan menjalankan hak asasi juga diatur oleh Kovenan Internasional Hak-hak Sipil dan Politik yang ditetapkan oleh Resolusi Majelis Umum 2200 A (XXI) Tertanggal 16 Desember 1966. International Covenant on Civil and Political Rights atau biasa disingkat dengan ICCPR ini pada prinsipnya berisi tentang pengukuhan hak-hak sipil dan politik yang bersumber dari martabat dan melekat pada setiap manusia yang dijamin dan dihormati keberadaannya oleh negara agar manusia bebas menikmati hak-hak dan kebebasannya dalam bidang sipil dan politik yang pemenuhannya menjadi tanggung jawab negara. Negara Indonesia sendiri telah meratifikasi ICCPR ini pada 28 Oktober 2005 melalui Undang-Undang Republik Indonesia Nomor 12 Tahun 2005, tentang Pengesahan Internasional Covenant on Civil and Political Rights (Kovenan Internasional Tentang Hak-Hak Sipil dan Politik). Pasal 20 ayat (2) ditegaskan:

“...Tidak diperkenankan untuk membatasi pelaksanaan hak ini, kecuali yang telah diatur oleh hukum, dan yang diperlukan dalam masyarakat demokratis untuk kepentingan keamanan nasional dan keselamatan publik, ketertiban umum, perlindungan kesehatan dan moral umum, atau perlindungan atas hak dan kebebasan dari orang lain. Pasal ini tidak boleh mencegah diberikannya pembatasan yang sah bagi anggota angkatan bersenjata dan kepolisian dalam melaksanakan hak ini". ${ }^{66}$

Sementara itu terkait dengan agama pada pasal 18 ayat (1-3) kovenan hak-hak sipil dan Politik menegaskan:

1. Setiap orang berhak atas kebebasan berpikir, keyakinan dan beragama. Hak ini mencakup kebebasan untuk menetapkan agama atau kepercayaan atas pilihannya sendiri, dan kebebasan, baik secara sendiri maupun bersama-sama dengan orang lain, baik di tempat umum atau tertutup, untuk menjalankan agama dan kepercayaannya dalam kegiatan ibadah, pentaatan, pengamalan, dan pengajaran.

harus memperhatikan hak orang lain, karena bangsa Indonesian yang pluralistis. Keanekaragaman yang ada harus diatur dan disepakati sehingga kebebasan bertindak yang dilakukan sesesorang tidak bertabrakan dengan kebutuhan warga Negara lainnya yang berbeda baik suku, ras, maupun agamanya.

66 Undang-Undang ini ditanda tangani oleh mantan presiden Susilo Bambang Yudhoyono pada tanggal 28 Oktober 2005 dan diundangkan pada tanggal dan tahun yang sama serta masuk dalam lembaran Negara Republik Indonesia tahun 2005 Nomor 119. 
2. Tidak seorang pun dapat dipaksa sehingga terganggu kebebasannya untuk menganut atau menetapkan agama atau kepercayaannya sesuai dengan pilihannya.

3. Kebebasan menjalankan dan menentukan agama atau kepercayaan seseorang hanya dapat dibatasi oleh ketentuan berdasarkan hukum, dan yang diperlukan untuk melindungi keamanan, ketertiban, kesehatan, atau moral masyarakat, atau hak-hak dan kebebasan mendasar orang lain. ${ }^{67}$

Berdasarkan Kovenan Internasional tentang Hak-hak Sipil dan Politik ini pun ditegaskan bahwa setiap orang mempunyai kebebasan menjalankan dan memenuhi haknya, tidak boleh diganggu orang lain, aparat pemerintah berhak mengatur atas dasar hukum demi untuk melindungi keamanan, ketertiban, kesehatan, atau moral masyarakat, atau hak-hak dan kebebasan mendasar orang lain.

Oleh karena itu pengaturan pendirian rumah ibadat sebagaimana diatur dalam PBM 2006 bukan merupakan bentuk diskriminasi mayoritas terhadap minoritas, tetapi untuk mengatur mekanisme hubungan pengguna tempat ibadah agar tertib aturan dan agar tercipta kondisi yang tertib dan rukun. Seperti disampaikan dalam sambutan Menteri Agama RI ketika memberi sambutan pada penandatangan PBM 2006 tersebut. Dikatakan bahwa prinsip yang dianut dalam Peraturan Bersama ini ialah bahwa pendirian sebuah rumah ibadat harus memenuhi peraturan perundang-undangan yang ada, kemudian dalam waktu yang sama harus tetap menjaga kerukunan umat beragama dan menjaga ketentraman serta ketertiban masyarakat. ${ }^{68}$

Pembatasan dalam hal ini adalah pengaturan agar dalam kehidupan bermasyarakat dan berbangsa aman dan tertib serta demokratis, maka perlu diatur dan diarahkan sebagaimana dalam Peraturan Bersama Menteri Agama dan Menteri Dalam Negeri RI nomor: 9 dan 8 tahun 2006. Terkait dengan pendirian rumah ibadat diatur dalam BAB IV pasal 13 yaitu:

1. Pendirian rumah ibadat didasarkan pada keperluan nyata dan sungguh-sungguh berdasarkan komposisi jumlah penduduk bagi

${ }^{67}$ Ibid.

${ }^{68}$ Sambutan Menteri Agama RI pada Sosialisasi Peraturan Bersama Menteri Agama dan Menteri Dalama Negeri RI Nomor 9 dan 8 Tahun 2006, tentang Pedoman Pelaksanaan Tugas Kepala Daerah/Wakil Kepala Daerah Dalam Pemeliharaan Kerukunan Umat Beragama, Pemberdayaan Forum Kerukuman Umat Deragama dan Pendirian Rumah Ibadat, tanggal 17 April 2007 dan lihat juga pada: http://www.depdagri.go.id/news/2006/04/17/sambutan-menteri-agama-ri- 
pelayanan umat beragama yang bersangkutan di wilayah kelurahan/desa.

2. Pendirian rumah ibadat tersebut dilakukan dengan tetap menjaga kerukunan umat beragama, tidak mengganggu ketenteraman dan ketertiban umum, serta mematuhi peraturan perundangundangan.

3. Jika jumlah umat tidak terpenuhi di tingkat kelurahan/desa, maka bisa digunakan batas wilayah kecamatan atau kabupaten/ kota atau provinsi. ${ }^{69}$

Menurut Ketua MUI H. Amidhan bahwa Peraturan Bersama Menteri Agama dan Menteri Dalam Negeri No 8 dan 9 Tahun 2006 masih sangat dibutuhkan untuk mengatur umat beragama dalam menjalankan kehidupan beragama. Ketua Majelis Ulama ini menilai, tidak ada yang diskriminatif dalam Peraturan Bersama Menteri Agama dan Menteri Dalam Negeri. Umat Islam di Bali dan NTT dan beberapa tempat lain juga mengalami kesulitan jika tidak memenuhi syarat. "Bagi umat Muslim di sebagian wilayah, membangun masjid juga tidak mudah seperti di Papua, di NTT, di Bali dan Sulawesi Utara. Tidak mudah itu".

Menurut mantan Menteri Agama, Suryadharma Ali, peraturan bersama dua menteri yang mengatur mengenai rumah ibadah tidak ada masalah sehingga tidak perlu direvisi, apalagi dicabut. Akan lebih baik jika peraturan itu ditingkatkan menjadi undang-undang. Konflik antarumat beragama di Bekasi, Jawa Barat disebabkan oleh faktor lain, bukan disebabkan oleh keberadaan peraturan bersama dua menteri. Konflik yang terjadi di Bekasi, merupakan persoalan kepatuhan terhadap peraturan yang mengatur mengenai rumah ibadah. ${ }^{70}$

Permasalahan PBM tahun 2006 sebenarnya terletak pada implementasi di lapangan secara proporsinal. Sering terjadi Organisasi Kemasyarakatan (Ormas) sebut saja Front Pembela Islam (FPI) atau

\footnotetext{
69 Peraturan Bersama Menteri Agama dan Menteri Dalam Negeri RI Nomor: 9 dan 8 tahun 2006, merupakan pedoman yang disusun oleh dan dari hasil diskusi para pimpinan Majelis-Majelis Agama Tingkat Pusat dengan draft dari Kementerian Agama dan Kementerian Dalam Negeri RI, yang dalam realitanya draft tersebut berubah dengan menjadi sembilan puluh persen lebih masukan dari para pimpinan majelis agama tersebut. Keputusan Bersama ini kemudian terkenal dengan sebutan PBM tahun 2006, yang ditanda tangani pada tanggal 21 Maret 2006.

${ }^{70}$ Suryadharma Ali pada rapat kerja dengan Komisi VIII DPR, di Gedung DPR, Jakarta, Selasa 21 September 2010, Sumber: http://m.dakwatuna.com/2010 /09/8883/peraturan-bersama-soal-rumah-ibadah-diusulkan-jadiuu/\#ixzz1m5hOYNdf
} 
yang lainnya yang sering mengatasnamakan Islam dan berdalih melanggar aturan dengan melakukan tindakan yang juga melanggar aturan lainnya. Persoalan implementasi PBM terletak pada sejauh peraturan ini dipahami oleh masyarakat dan dilaksanakan dengan sebaik-baiknya. Yang jelas peraturan bersama ini dibuat untuk menjaga persatuan dan kesatuan serta menciptakan masyarakan yang rukun dan toleran.

Terlepas dari perdebatan apakah PBM Tahun 2006 itu relevan dengan era demokrasi dan menjaga HAM atau tidak, yang jelas fungsi pengendalian sistemik yang dianggap efektif adalah perlunya melakukan sosialisasi PBM intensif dan menyentuh hingga akar massa. Hal ini perlu dilakukan karena akar massa adalah elemen masyarakat yang paling mudah untuk disulut menjadi pemicu konflik terbuka. Dengan dipahaminya aturan PBM Tahun 2006 ini diharapkan masyarakat paham tentang aturan pendirian rumah ibadat, sehingga jika terjadi persengketaan tentang pendirian rumat ibadat maka dapat dikembalikan kepada aturan hukum yang telah disepakati dan ditetapkan.

\section{Penutup}

Relasi antarumat beragama di Driyorejo sangat baik, yang ditandai dengan hubungan yang saling menghormati dan toleran dalam rangka pelaksanaan ajaran agama masing-masing di wilayah tersebut. Secara fungsional hal ini menunjukkan ada proses adaptasi yang sangat baik antarpemeluk agama. Keharmonisan tersebut dapat dimaknai bahwa tujuan bersama masyarakat Gresik adalah merealisir masyarakat yang tertib, aman, dan tenang. Elemen-elemen sosial keagamaan dapat diintegrasikan secara padu untuk mencapai tujuan mewujudkan masyarakat yang utuh dan bersatu. Keharmonisan tersbut dapat tercapai karena ada tata nilai budaya religius masyarakat Gresik yang lebih mengawalkan sikap akomodatif dan toleransi (latency).

Problem sosial terkait dengan pendirian gereja-gereja di Perumahan Non-Dinas TNI AL Driyorejo Gresik memang sempat menimbulkan keresahan masyarakat. Keseimbangan sistemik masyarakat memang rentan berubah karena pengaruh ekstra sistem. Ini menunjukkan instabilitas sistem sosial dalam masyarakat Gresik. Akan tetapi tiap sistem sosial memiliki mekanisme pengendalian internal yang dapat menstabilkan kembali sistem yang mengalami gangguan. Dalam kasus pendirian gereja-gereja, masyarakat Gresik 
cenderung memilih langkah hukum sebagai pengendali konflik atau gangguan yang meresahkan.

\section{Daftar Rujukan}

\section{A. Buku}

Ahmad, Haidlor. "Studi Kasus Perselisihan terkait Pendirian, Penertiban dan Penutupan Rumah Ibadat di Kota Kupang Nusa Tenggara Timur", Haidlor Ali Ahmad (ed.), Haidlor Ali Ahmad (ed.), Hubungan Umat Beragama: Studi Kasus Penutupan/Perselisiban Rumah Ibadat. Jakarta: Badan Litbang dan Diklat Puslitbang Kehidupan Keagamaan Kementerian Agama RI, 2012.

Ali, Mursyid. "Studi Kasus Rumah Ibadat di Kota Palangkaraya Kalimantan Tengah", Haidlor Ali Ahmad (ed.), Haidlor Ali Ahmad (ed.), Hubungan Umat Beragama: Studi Kasus Penutupan/Perselisiban Rumah Ibadat. Jakarta: Badan Litbang dan Diklat Puslitbang Kehidupan Keagamaan Kementerian Agama RI, 2012.

Amal, M. Khusna. "Komitmen Agama Merajut Kerukunan Otentik di Perkotaan", Dialog Jurnal Penelitian dan Kegamaan, No. 65, Th. XXXI, Juli, 2008.

Aminah, Siti dan Sihombing, Uli Parulian. Memahami Kebijakan Rumab Ibadah. Jakarta: The Indonesian Legal Resource Center (ILRC), 2010.

Anderson, Bennedict. Imagined Communities: Komunitas-komunitas Terbayang, terj. Omi Intan Naomi. Yogyakarta: Insist-Pustaka Pelajar, 2001.

Arifin, Syamsul et. al. Pluralisme Keagamaan di Pedasaan: Studi Pola Interaksi Sosial Tiga Kelompok Agama (Islam, Kristen, dan Budha). Jakarta: Seri Penerbitan Ditjen BAGAIS Kemenag, 2004.

Asry, M. Yusuf. "Studi Kasus tentang Perselisihan, Pendirian Rukmah Ibadat di Kota Tangerang Selatan Provinsi Banten", Haidlor Ali Ahmad (ed.), Haidlor Ali Ahmad (ed.), Hubungan Umat Beragama: Studi Kasus Penutupan/Perselisiban Rumah Ibadat. Jakarta: Badan Litbang dan Diklat Puslitbang Kehidupan Keagamaan Kementerian Agama RI, 2012.

Hakim, Bashori A. "Studi Kasus Perselisihan tentang Pendirian, Penertiban, dan Pentupan Rumah Ibadat di Kabupaten BadungBali", Haidlor Ali Ahmad (ed.), Haidlor Ali Ahmad (ed.), Hubungan Umat Beragama: Studi Kasus Penutupan/Perselisiban Rumah 
Ibadat. Jakarta: Badan Litbang dan Diklat Puslitbang Kehidupan Keagamaan Kementerian Agama RI, 2012.

Kalikin, Ahsanul. "Pendirian Rumah Ibadat dalam Perspektif PBM:

Kasus Pencabutan IMB Gereja HKBP Pangkalan Jati Gandul Kecamatan Limo Kota Depok", Haidlor Ali Ahmad (ed.), Haidlor Ali Ahmad (ed.), Hubungan Umat Beragama: Studi Kasus Penutupan/Perselisiban Rumah Ibadat. Jakarta: Badan Litbang dan Diklat Puslitbang Kehidupan Keagamaan Kementerian Agama RI, 2012.

Kholil, Muhammad. "Pluralisme Agama: Telaah Kritis atas Pemikiran Nurcholis Madjid”. Tesis-IAIN Sunan Ampel Surabaya, 2008.

Liliweri, Alo. Prasangka dan Konflik. Yogyakarta: LKiS, 2005.

Muchtar, Ibnu Hasan. "Studi Kasus terkait Perselisihan, Penertiban, dan Penutupan Rumah Ibadat di Kota Penelitian di Kota Jayapura", Haidlor Ali Ahmad (ed.), Haidlor Ali Ahmad (ed.), Hubungan Umat Beragama: Studi Kasus Penutupan/Perselisiban Rumah Ibadat. Jakarta: Badan Litbang dan Diklat Puslitbang Kehidupan Keagamaan Kementerian Agama RI, 2012.

Ritzer, Goerge dan Goodman, Douglas J. Teori Sosiologi Kontemporer, terj. Alimandan. Jakarta: Prenada Media, 2004.

Ruhana, Akmal Salim. "Studi Kasus Perselisihan terkait Pendirian, Penertiban, dan Penutupan Rumah Ibadat di Kota dan Kabupaten Bogor Jawa Barat", Haidlor Ali Ahmad (ed.), Haidlor Ali Ahmad (ed.), Hubungan Umat Beragama: Studi Kasus Penutupan/Perselisiban Rumah Ibadat. Jakarta: Badan Litbang dan Diklat Puslitbang Kehidupan Keagamaan Kementerian Agama RI, 2012.

Suwariyati, Titik. "Studi Kasus Pembangunan Gereja Kristen Bethany Indonesia dan Gereja Katolik Santo Gabriel di Perumnas Kota Baru Driyorejo Kecamatan Driyorejo Kabupaten Gresik", Haidlor Ali Ahmad (ed.) Haidlor Ali Ahmad (ed.), Hubungan Umat Beragama: Studi Kasus Penutupan/Perselisihan Rumah Ibadat. Jakarta: Badan Litbang dan Diklat Puslitbang Kehidupan Keagamaan Kementerian Agama RI, 2012.

Suwariyati, Titik. "Studi Kasus Pembangunan Gereja Kristen Bethany Indonesia dan Gereja Katolik Santo Gabriel di Perumnas Kota Baru Driyorejo Kecamatan Driyorejo Kabupaten Gresik", Haidlor Ali Ahmad (ed.), Hubungan Umat Beragama: Studi Kasus Penutupan/Perselisihan Rumah Ibadat. Jakarta: Kementerian Agama 
RI, Badan Litbang dan Diklat Puslitbang Kehidupan Keagamaan, 2012.

Tualeka ZN, Hamzah. "Konflik dan Integrasi Sosial Bernuansa Agama: Studi Tentang Pola Penyelesaian Konflik Ambon-Lease Dalam Perspektif Masyarakat". Disertasi--IAIN Sunan Ampel Surabaya, 2008.

Ulfa, Isnatin. "Perspektif al-Qur'an tentang Pluralisme Agama: Telaah Komparatif terhadap Pluralisme Agama dalam Tafsir al-Bayan dan Tafsir al-Mizan". Tesis--Surabaya: PPs IAIN Sunan Ampel, 2003.

Zainuddin. "Relasi Islam-Kristen: Konstruksi Elit Agama tentang Pluralisme dan Dialog Antarumat Beragama di Malang". Disertasi--IAIN Sunan Ampel Surabaya, 2008.

\section{B. Wawancara}

Iksan, Ashadi (pengurus GP Ansor Gresik). Wawancara. Gresik 4 November 2014.

In'am, M. (Tokoh Muhammadiyah dan Pengurus FKUB Gresik). Wawancara. Gresik 27 Mei 2014.

----. Wawancara. Gresik 9 November 2014.

----. Wawancara. Gresik 23 Mei 2014.

Irfan, Yohanes (tokoh agama Katolik). Wawancara. Gresik 4 November 2014.

----. Wawancara. Gresik 14 November 2014.

-----. Wawancara. Gresik, 8 Juli 2015

Makmun, H. (tokoh Agama NU Gresik). Wawancara. Gresik 16 Mei 2014.

Maksum, K.H. Afif (Ketua FKUB Kabupaten Gresik). Wawancara. Gresik 27 Mei 2015.

Najib (Penyuluh Agama Kecamatan Driyorejo). Wawancara. Gresik 12 Mei 2014.

Qosim, H. Moh. (Wakil Bupati Gresik). Wawancara. Gresik 16 Mei 2015.

Rande, Martinus. Wawancara. Driyorejo, Gresik 12 Juli 2015.

Setorini, Pdt. Ari (pembina agama Kristen Jawi Wetan di Gresik). Wawancara. Gresik 8 Juli 2015.

Sururi (agamawan sekaligus penggerak pemuda). Wawancara. Gresik 12 April 2014. 
Sutiono (Pengguna Gereja dari agama Kristen Jawi Wetan). Wawancara. Driyorejo Gresik 12 Juli 2015.

Toha, Muhammad (Kepala Balai Diklat Surabaya). Wawancara. Gresik 18 April 2014.

Vitus S. Y. (anggota TNI AL dari agama Katolik). Wawancara. Gresik 12 Juli 2015.

Wagino, H. (Warga Perumahan Non-Dinas TNI AL). Wawancara. Gresik 15 Mei 2014.

Yarham (Pengurus FKUB Kabupaten Gresik). Wawancara. Gresik 29 Mei 2014. 